\title{
Orimupiko 22 and the Haze of History ${ }^{1}$
}

\author{
RACHEL BUCHANAN
}

Certain types of chaotic events lure historians and readers. While giving birth is a chaotic, exceptional, creative event it is also a private, universal and prosaic one. While not all women will give birth, all men and women have been born. Wars and natural disasters, however, present a different order of chaos. They are destructive, exceptional and public. Wars and disasters rupture time. What once existed is no more. People die. Mountains collapse. Homes burn. Ships shatter. Villages empty. Residents flee. Roads split. Swamps rise. Forests fall. Some of these events are over in a flash. A dormant fault-line shudders, the earth shakes, buildings crack and crumble and collapse, people are crushed. Others, like wars, go on and on, spreading and intensifying the chaos, knifing time and splitting it apart.

One of the jobs of the historian is to create a narrative that makes sense of disturbing events, either distant or more recent, and so bring order to chaos. Many relish this challenge. 'Battles are notoriously difficult phenomena to reconstruct,' warned James Belich in the introduction to the revisionist history of the New Zealand Wars that made his career. ${ }^{2}$ Belich responded by constructing a thematic 'overview' of events, one that necessarily erased the mess and confusion of so many bloody moments by concentrating on the motivations of leading individuals and broad categories of people: 'Europeans' and 'Māori'.

Another path focuses upon on chronology and so construct a before, during and after of a disaster. This was the structure adopted by Australian military historian Peter Stanley in his book about the 2009 Black Saturday bushfires at Steels Creek, a small rural community on the fringes of Melbourne. ${ }^{3}$

The overview and the chronological approach both required a narrator who was able to step back from the events in question and write with a 'cold' rather than a 'hot' head. ${ }^{4}$ 'My main justification for writing about battles or fires is that I have skills in interpreting chaotic experiences and a necessary detachment in doing so', Professor Stanley wrote in his acknowledgment. 'While a survivor of battle or bushfire will recall their own experience of the event - whether vividly or vaguely - they will often have a hazy idea of how it fits into the bigger picture across the battlefield, or, as the fire services say, the fireground. ${ }^{5}$ In the book's foreword, fire survivor Andrew Chapman said Stanley wished to 'draw all the facts together and bring sense to the disorder - not an easy task'. ${ }^{6}$

Both books are strong works of history: humane, vigorous, intellectually adventurous and courageous. This article is also about a disastrous event - the Taranaki Wars and their aftermath - but it proposes another way of making history about chaos. Instead of 'detachment' and 'dispassionate analysis' I write from a stance that is personal, passionate, emotional, specific and 'attached'. 'My decision to write this way springs from more than a decade of struggle with 'kaupapa Māori' research methodologies - which advise, among many other things, that a researcher tackle subjects connected with their own iwi [tribe] - and from my intimate connection with the war I am researching. ${ }^{8}$ It has also been influenced by the work of Laura Troiano, a young American historian of prohibition who writes history 'in pieces' or 'in process' to demonstrate that 'writing styles can be more than a vehicle for an argument: they can, in fact, be the argument'.

In this article, I demonstrate that 'attached' writing can also be historical, forensic and analytical. More significantly, the style of writing and narration argues that some chaotic events resist explanation, slip free of the bigger picture and blur standard historical chronologies. For certain chaotic events, a researcher can do extensive archival research, fieldwork, oral history collection, secondary source reading and all the rest and still have only a 'hazy idea' of what actually happened. Such is the situation with Orimupiko 22, a 29- 
hectare block of Māori freehold land in Taranaki, a remnant of a much larger block granted to my Taranaki tupuna [ancestors] as part of the West Coast Settlement Reserves Act $1884 .^{10}$

I started my research with the aim of improving whanau [extended family] knowledge about this land and the research has achieved this. ${ }^{11}$ But I also wanted to find a broader meaning beyond this family significance and to track how our experience with this block fitted into a much 'bigger picture', namely the 1.466 million hectares of land in New Zealand that is still Māori freehold. This precious land is particularly worthy of attention because it unsettles the frameworks of Waitangi Tribunal claims and even Treaty settlements; both these processes deal with what has been lost rather than with what has been retained. Māori still 'own' freehold land, no matter how complex and fraught this ownership might be. We do not have to demand this land be returned. It is still 'ours'. Our relationships - positive and negative - with this land are played out in the Māori Land Court, a place quite apart from the Tribunal or Office of Treaty Settlements.

One type of Māori land is 'raupatu' land, namely land that was confiscated by the Crown - under the New Zealand Settlements Act of 1863 - in punishment for Māori rebellion. Much raupatu land was alienated permanently but a portion of it was subsequently returned. Historians Richard Hill and Richard Boast have asserted that raupatu has been overlooked in New Zealand history. ${ }^{12}$ Some scholars argued that enough specific research had been done mostly by historians working for the Waitangi Tribunal - and what is now required are more 'generalised thematic discussions', but Boast and Hill wrote that 'not nearly enough is known about the details of confiscation'. ${ }^{13}$ Spurred by this observation, I began hunting for such detail on Orimupiko 22 and I hoped my micro-history would illuminate some broader truths.

The task was urgent. Māori freehold land comprises about 5.5 per cent of New Zealand's land mass [the rest is classed as 'General land'] and it is under renewed political scrutiny. In 2012, the National government announced a review of Te Ture Whenua Mãori Act 1993 and flagged its intention to 'improve the performance and productivity of Māori land'. In March 2013, a discussion document was released. In the foreword, Minister for Māori Affairs Pita Sharples and Associate Minister Christopher Finlayson said 'eighty per cent of Māori land is currently underdeveloped and ignored by some disengaged owners'. ${ }^{14}$ The review panel has proposed significant changes to the administration of Māori land, including a diminished role for the Māori Land Court, new categories of owners ('engaged' versus 'disengaged'), the provision to appoint external managers for land owned by 'disengaged' or absent owners and new rules to simplify succession and prevent 'excessive fragmentation' of ownership. ${ }^{15}$ These changes are sensible but also radical. Many hinged on a strong implied criticism of 'disengaged' owners although the discussion document did not address the multiple reasons for owner 'disengagement', which could include ignorance, despair, infighting, skullduggery and fear. My research - in all its emotional messiness illuminates some of the reasons for owner 'disengagement' and so this article makes a practical contribution to a current political inquiry while also offering a methodological challenge to some disciplinary norms in writing about war and other disasters. ${ }^{16}$

\section{Taranaki and the 'chaos' of confiscation}

Most Māori land is in the east, north and centre of the North Island. While Māori in other parts of the North Island responded to land loss by either remaining 'neutral' or by fighting alongside colonial troops against common enemies, in Taranaki people decided to openly oppose the government via either armed or passive resistance. In hindsight, these were not good strategies for retaining land. A map produced for the Ministry of Agriculture and Fisheries in 2010 provides simple visual proof of this. ${ }^{17}$ The East Coast knuckle that radiates out from Gisborne is almost all shaded a dark purple to denote Māori freehold land. The West Coast one, meanwhile, is pricked with the smallest of purple dots. 
The dots, which include Orimupiko 22, are a memorial to the nineteenth-century wars that ravaged Taranaki. Much has been written about the exceptionally drawn out and chaotic nature of this fighting. First tribes from the Waikato and Hokianga invaded Taranaki in the early-nineteenth-century and this fighting emptied out the region. People were killed or taken prisoner. Meanwhile, hundreds more fled south to Waikanae and what is now known as Wellington. ${ }^{18}$ Then people started to return, just in time for the next wave of fighting, this time against the British Crown and later the New Zealand government. The New Zealand Settlements Act of 1863 confiscated most land in Taranaki as a punishment for Māori 'rebellion' at Waitara in 1860 (for example, Te Ati Awa men returned fire after the British army shot canons and rocks at Te Kohia pā). ${ }^{19}$ As Michael Belgrave put it: 'The large scale confiscation of Māori land in Taranaki that occurred during the war contributed to the war's continuation, and was implemented with an unprecedented level of confusion and contempt for legal processes or for promises made to Māori, even those who remained neutral or supported the Crown'. ${ }^{20}$

Belgrave built on the theme of confusion, especially the period between 1863 and 1884, which included 'Titokowaru's war' in south Taranaki in the late 1860s, the non-violent resistance campaign of Parihaka in the 1870s and the subsequent Crown invasion and ransacking of the settlement in 1881. 'What occurred in Taranaki ... was a mess: a muddle of confusing activities, policies and player,' he wrote. ${ }^{21}$ Further, the wars and confiscations were 'very different' in Taranaki compared with the rest of New Zealand and this 'difference' had 'enduring consequences for the province as a whole but also for Taranaki hapu. ${ }^{22}$ In a research report for the Waitangi Tribunal, Janine Ford observed that in Taranaki only a fifth of the land that was confiscated was returned but even then, most 'Māori' land was administered by the Public Trustee and leased, compulsorily, to Pākehā tenant farmers. 'In no other raupatu district were the returned confiscated lands dealt with in this way,' Ford wrote. ${ }^{23}$

Indeed, Ford argued, the trust system was only introduced in Taranaki because of the ongoing threat Parihaka leaders Te Whiti and Tohu posed to the government. ${ }^{24}$ Imposing external management on Taranaki Māori land was seen as a way of preserving peace and promoting European settlement. These perpetual leases - and the little understood shorterterm leases that exist on blocks such as Orimupiko 22 - are little land mines embedded in Taranaki Māori families, including my own. But they are also a rope that links us, intimately, with Parihaka and its revolutionary leaders whose simple message was 'Land, Mine!'

\section{There's a buried forest on my land}

In May 2012, my father, my youngest daughter and I turned off Eltham Road and into a farm gate. We were looking for our ancestral Taranaki iwi land. Our whānau has owned this land for many generations but none of us had ever walked on it. Just inside the gate, there was a modest house and a big shed. A tractor and a ute were parked out the front of the shed. A thick-set, bald man in a checked shirt was leaning against the ute. He was smiling and relaxed. A silky brindle dog did circles at his feet.

I felt nervous. Dad was nervous too. Dad parked the car, hopped out and shook the farmer's hand. The dairy farmer's name is Karl Mullin. Dad went to school with Karl's dad John. Both of them were boarders at St Joe's in Masterton. Much later, in early middle-age, the two men had met again when my father, a paediatrician at Taranaki Base Hospital, had treated one of John's sons, a boy of two or three with a life-threatening condition. The baby had subsequently died. 'I remember you,' Karl said to my father. 'You cared for my brother. ${ }^{, 25}$ No doubt John Mullin had remembered all this too, when Dad had phoned him the week before to ask for permission to visit Orimupiko Block 22. Dad had not mentioned the sick child to me at all. Medical ethics would prevent it. 
But the dead child was there with us now, just for a moment. Karl's face softened. I saw a shadow of something, sadness or fear. I don't know what. My father said nothing. My daughter, Frances, just six, put her plump wee hand in mine and looked at her feet. Her whitegold hair was tied back but pieces had escaped and the Taranaki damp had frizzed these strands into a fuzzy halo around her dear pink face.

Karl offered to show us around. 'That's your land,' he said. 'It runs from the fence-line down to the river.'

Our eyes followed Karl's finger, taking in the paddocks, the fences, the ditches, the small stand of remnant native bush and the lovely curl of the river - the Waiaua - wrapped around the southern edge of our small patch of Opunake. This bit of land was excellent, Karl said. The best in the district. It was flat and fertile and free from lahars.

On a clear day, the mountain would loom up over the farm but today he was covered in clouds, from foothills to summit. 'The mountain doesn't come out for visitors,' Karl said pleasantly. It was time to get moving. Frances and I sat in the back of the ute and Dad and Karl hopped in the front. Karl's dog Oscar panted up the back. The dog leapt up to try and lick Frances' soft little neck. Frances giggled happily. I looked out the window as if in a dream. Karl knew everything and I knew nothing. Karl knew the boundaries of our block and the boundaries of the other Māori blocks too. The rest of the farm had been West Coast Settlement Reserve land too, he said looking over his shoulder back towards the mountain, but his father, John, had 'converted' it some time ago so the Mullins owned it outright.

I did not have the words to explain what I felt. Perhaps I was happy. Or maybe I was meek and grateful. Certainly there were other sensations too: anger; sorrow; rage; total disbelief. There is certainly no term in the English language to express my situation. I was less than nothing. I was an invited guest on my own land. The tenant was the host. The land that was 'ours' was, manifestly, 'his'. The land was an orphan, adopted his family, abandoned by ours.

We bumped along down towards the river then back up the hill again. On the top of an incline, just above the bush and the rusted rim of a car, a tattooed man chopped up large, black, rata logs. Karl used the logs for firewood. They burnt really well. 'If you dig down deep enough here, you'll find natives,' Karl explained.

Similar trees lay beneath the entire block, making it difficult to dig ditches or lay drains. 'Something came through here,' he said. 'A big land slide and it pushed all of them over.' The trees all pointed in the same direction, seawards. There's a buried forest beneath our land. Later, when I mentioned the day to Frances, she was enthusiastic about the time she spent 'on farmer Karl's farm'. Oscar the dog made a big impression but so did the hawk we saw as we left.

\section{Where are they now?}

The accountants in Wanganui had sent the slip of paper to Dad and 71 others. The slip said: 'Attached is a list of owners in Orimupiko 22 Trust that we do not have addresses for. If you know where any of these people live could you please send us their details in the enclosed envelope.'

Thank you.

When I looked at 21 names on this list, I saw birds pattering about on a wet, windy beach. The birds were all very far apart. The weather was so bad that they could not see further than their feet. The rain had played a trick on them. First the birds could not see the flock and then they forgot that the flock was even there.

\section{Spicks and specks}


Go to the Ministry of Justice. Then go to the Māori Land Court. Then go to Māori Land Online. Type in Orimupiko Block 22. A map will pop up. The block is shaded dark grey. To the north, the map is white, just as Karl said. Look left, more grey. Look down, grey again. Roll the mouse back and still more grey appears in varying forms: fat rectangles, skinny oblongs, boxes with deckle edges, a triangle, a block shaped like a beak, tiny dots and squiggles right by the sea. All pieces for a puzzle that we can no longer complete because there are too many bits missing, whited out, emptied out, alienated, confiscated, sold.

1975

My cousin Paul Walker met my grandmother Rawinia once. It was 1975 and Paul, his mum Doreen and Flossie were three of the owners of Orimupiko 22 who had been summoned to Wellington for a meeting about the block. Everyone had to come, apparently. If people failed to show up, then the land would be sold or taken. 'I remember the day quite well,' Paul told me, 'because it was the day the land march arrived in Wellington.' 26

\section{Play-time}

The 1915 Partition Order for Orimupiko Block 22 was issued under Section 21 of the West Coast Settlement Reserves Amendment Act 1913 and 1914 and the Native Land Act 1909. I have counted up all the relevant legislation for Block 22. My list begins with the New Zealand Settlements Act of 1863 and ends with the Maori Reserved Lands Amendment Act $1997 .{ }^{27}$ The list is very long but almost certainly incomplete. My land is a play in 21 Acts. Stop playing with my land.

\section{Trustee}

Robert Hamerton was the first Public Trustee appointed to administer the West Coast Settlement reserves. He had arrived in New Plymouth, from Lancashire, in 1854, aged 16. Six years later, he became an ensign for the Taranaki Rifle Volunteers, rising, eventually, to the rank of captain. ${ }^{28}$ The New Zealand Settlements Act of 1863 confiscated most land in Taranaki. Māori were never given any of the promised reserves, a failing that the non-violent activist community at Parihaka attempted to highlight and address. In 1880 the West Coast Commission's recommendations led to an Act that awarded 201,395 acres to 5289 individuals. ${ }^{29}$ The former soldier, Hamerton, was put in charge of the reserve land. He held a pen instead of a rifle but the result was quite similar.

\section{War memorial}

Ko tēnei te wā...

$\mathrm{O}$ te pakanga nui

Haururu ana te ao

Ko tēnei te wā

$\mathrm{O}$ te pakanga roa

Uira ana te ao

Ko tēnei te wā

$\mathrm{O}$ te pakanga wehi

Murara ana te ao

Ee...i....i

Taukuri e! 
Murara ana te $\mathrm{ao}^{30}$

Katarina Mataira's epic 1975 verse novel Te Atea begins with these powerful lines, which Mataira has translated as: 'This is the time of the great war. The world reverberates. This is the time of the long war. Lightning flashes. This is the time of the fearsome war. The world is aflame. Aweeah. The world burns.' In Mataira's story, the people escape a poisoned, warridden world by blasting off into space. My ancestors had nowhere else to go. After the great wars and the burning and looting, they had to stay. Every block of Māori land in Taranaki is a war memorial.

\section{Long Division}

On 2 July 1883 that year, 18 months after the Crown had invaded and ransacked Parihaka, the new governor of New Zealand, William Francis Drummond, granted Ihaia Ngakirikiri and 49 others 6900 acres of land in the Opunake Survey District. Grant 3924 was 'Bounded towards the North West by the Waiaua River and by Waste Land and a Public Road ... towards the North East by the Forest Reserve ... towards the South East by the Kaweora Road and the Pukekohatu Block ... and towards the South West by the Sea Coast. ${ }^{31}$

Two days later, the Commission of Crown Lands and the Public Trustee granted 23 different leases on the block to Pākehā farmers. Dudle, Moore, Joy, O'Sullivan, Hickey, Hopper, Clarke, Higgins and Kirkwood are some of the names I can make out. In fact, Thomas Mackay, the Reserves Trustee, 'succeeded in securing the immediate lease of 10,000 acres of the Opunake block in less than 2 hours' ${ }^{32}$

The owners of blocks both north and south of Parihaka were charged for surveying, fencing, draining and road building costs. Roads were the most expensive. My ancestors had to pay for the roads that were built through land that they would never be able to farm. Over five years, five shillings per acre was deducted from the rents of all leases to pay for road construction. Two Orimupiko roads were included. The Ihaia cost $£ 275$ and the Kaweora cost $£ 280$ and my relatives had paid for all of it. ${ }^{33}$

Māori owners received minimal rents from their tenants and Reserves Trustee Wilfred Rennell admitted that rents were particularly low in Opunake, especially once money for roads and surveys had been deducted. 'He informed the Public Trustee that in one grant, only 4 pounds 4 shillings $4 \mathrm{~d}$ had been available for division among 51 grantees, while in another, no rents were available'. ${ }^{34}$ Meanwhile settlers claimed their rents were too high and many either refused to pay or negotiated significant reductions. As if nothing was too much, from 1887 onwards, a new law - the West Coast Settlement Reserves Acts Amendment Act 1887 made it lawful for the Public Trustee to delay proceedings to recover unpaid rent by up to 12 months. ${ }^{35}$ No interest was ever charged on late rent. Many settler farmers continued to refuse to pay rent at all. ${ }^{36}$

In February 1887, the Native Land Court subdivided the remaining unleased land in Orimupiko into 24 blocks. Entries in the Taranaki Minute Book No.3, noted the division had been 'made under the West Coast Settlement Act 1884 Clause 15 and has been accepted by the claimants as a basis of the acreage to be apportioned to individuals in the present subdivision'. ${ }^{37}$ Ihaia Ngakirikiri made a list of names of people to be given land but witnesses in 1909 hearings said the many of the people on the original title were living at Parihaka in 1887 and so they had been left out. None of those living at Parihaka accepted rent money from the block. ${ }^{38}$ Others on Ihaia's list, though, including Mohi and Te Awhe Parai, had not long been released from Lyttelton jail, where they had been exiled for their part in the passive resistance protests.

The Block Order file contains a partition order that notes Section 13, Block 8 Opunake Survey district (total 342 acres) was owned by Te Awhe Parai, Mohi Parai, Poihi Mango, 
Turia Warahi and Tare Warahi. Later, in a different hand and a darker ink, someone has written No. 19 Orimupiko at the bottom of the page.

The perpetual leasing regime was introduced, in Taranaki, in 1892. The West Coast Settlements Reserves Act said 'all West Coast settlement reserves except Compensation Court awards and special awards were to be vested in the Public Trustee in fee simple (ie Māori lost the freehold) and could be leased at his discretion for 21 years with the right of perpetual renewal. ${ }^{39}$ Although my whānau are shareholders in Parininihi Ki Waitotara [PKW] - the dynamic incorporation that now administers the 20,000 hectares of remaining West Coast Settlement Reserve land - Orimupiko remains separate. ${ }^{40}$ For reasons that remain hazy, Orimupiko was never subject to these perpetual leases and nor were many other small blocks around Taranaki. Our block does not fit the dominant narrative presented by Dion Tuuta and by the Waitangi Tribunal research reports. Instead, our block had its own particular progression through the court and the trustees. Its story is part of what Tuuta has described as 'the complex, convoluted and shambolic history of the awards, leasing system and administrative arrangements', arrangements that have 'denied us real control over our property'. ${ }^{41}$ There are dozens of similar blocks to ours in Taranaki and the history of this whenua is yet to be told.

Aside from a few succession orders, between 1887 and 1915, the Orimupiko Block Order file is silent but my ancestors did not accept their exclusion from their land and in 1892 Ihaia Ngakirikiri and 70 others 'petitioned Parliament requesting that their lands be exempted from the West Coast Settlements Reserves Acts and that they, not the Public Trustee, should have control of their lands'. ${ }^{42}$ Hundreds of others complained too and in 1906 a Royal Commission was set up to inquire into the administration of the West Coast Settlement Reserves. ${ }^{43}$ In 1909, Maui Pomare and Robert Tahupotiki Haddon, a Methodist clergyman, set up a union to push for some West Coast reserves to be made available for Māori occupation. They wanted to encourage young people to leave Parihaka and start farming instead. Pomare said Māori sought 'some road by which our lands leased by the Public Trustee for all time be returned to us, as we realise that in order to avert extinction we must become active farmers, and not mere rent receivers'. ${ }^{44}$ A further Royal Commission investigated the reserves in 1912.

In 1915, the Native Land Court eyed Orimupiko again. Apparently, the Public Trustee did not enforce this 1887 subdivision ruling and in 1915 Judge Black, found that initial partition was 'now in some respects inapplicable to the altered circumstances'. The court cancelled it. It made a new order, chopping up Orimupiko into 24 different blocks. Orimupiko 1 comprised the urupa Matakaha and a tauranga waka at the mouth of the Waiaua River - a very significant site, the place where Pai Marire founder Te Ua Haumene lived. The Court ordered it 'be cut off by the most convenient lines as seen by the Surveyor on the ground' ${ }^{45}$

Orimupiko 22 (148 acres or 127 acres depending on the paperwork, being sections 16, $18 \& 19$, Blk X) our little part of the prize, was given to six people: Awhe Parai, Mohi Parae, Tare Warahi, Tapuiatini Warahi, Hone Turia Warahi and Takarete Warahi. The unleased residue of the block was vested in the Public Trustee under the West Coast Settlement Reserves Act 1892 and the Orimupiko 1892 Act Leases. Meanwhile succession continued on other Orimupiko land that stemmed from the supposedly unenforced 1887 partition. This included land held by Turia Warahi, Tare's sister.

Between 1921 and 1932, some 2030 acres of land from the original Orimupiko reserved land was purchased and proclaimed as Crown land. The biggest taking was at Orimupiko no. 1 , the land by the coast where the urupa is today - 820 acres were went for $£ 1267$. $^{46}$

This figure includes sales within our block too. In less than 15 years, all of Orimupiko 22 was alienated by either sale or lease. In 1929, Takarete Warahi [also known as Ellerslie Harrison], a daughter of Turia Warahi and James Harrison, sold 16 acres of the block to John 
Harrison - her brother. The District Māori Land Board listed the reason for the sale as 'natural love and affection'. In 1931, all of section 16 (76 acres out of a total of 148) was sold to Isaac Short, an Opunake farmer, for £912. On 12 May 1933, the remaining 64 acres was leased, for 10 years at a rent of $£ 45$ a year, to Matai Parai of Paraparumu. Parai, a farmer, was the son of one of the original owners, Te Awhe, a Parihaka ploughman. Parai's lease expired on 31 December 1941.

On 9 June 1945, at a sitting in Hawera, the Native Land Court declared 'the said land is unleased and unoccupied and is not kept properly clear of noxious weeds'. The Court 'is of opinion that it is in the interests of the owners of the said Block and in the public interest that the property should be alienated'. The Court - 'in pursuance of the powers vested in it by Section 540 of the Native Land Act 1931 doth hereby appoint the Native Trustee to execute in his own name as agent for and on behalf of the owners of Part Orimupiko 22 being Sections 18 and 19 Block X Opunake S. D. an instrument of alienation of the said Block by way of lease'. ${ }^{47}$

On 1 December 1945, the remaining 72 acres in the block was leased to Isaac Short, the farmer who had brought the other half in 1931. He signed a lease for 10 years; the rent was $£ 45$ a year.

My great-grandmother, Hannah Bramley (nee Wallace) wrote to the Māori Land Court in 1942 asking about Orimupiko 22 and about the interests of her tupuna there. The Court sent her particulars of the title of Part Orimupiko 22 'together with a list of the owners of same'. In 1947, the Native Department wrote to Grandma to let her know that 'a block of 72 acres is leased to Isaac George Short of Opunake, farmer who transferred his lease to Hugh Joseph Mullin of Opunake, farmer. The lease is for 10 years from 1/12/45 at a yearly rate of $£ 45$ pounds and this amount is payable to the Native Trustee, Wellington'. ${ }^{48}$

A 1975 commission of inquiry into Māori Reserved Land found beneficial owners had been 'assigned a completely passive role in the management of the reserves'. They had been 'treated as children under a disability' and had not been 'well informed upon the law or the facts concerning the lands in which they have an interest'. ${ }^{49}$

Hugh Mullin is Karl's grandfather. He came to New Zealand from County Tyrone, Ireland. Karl's son is called Tyrone. The Mullin farm is administered by the Six Mile Trust. The Trust is named after the Irish village where Hugh was born.

\section{The writer's block}

I have made my living from writing since I was 18 . I often find writing a challenge but two careers - journalism and academia - mean that writer's block is not a luxury I have been able to afford for too long. Until 2012, the year I discovered my very own Writer's Block, Orimupiko No. 22, and a Block Order File to go with it.

Block order files are kept at Māori Land Court offices around New Zealand. The court is unique; it is the only one in the world structured around whakapapa [genealogy]. There are special booklets to explain how it all works: trust, succession, leases and all the rest. The opening paragraph of each booklet is the same. The second sentence says: 'The special bond between Māori people and the land is recognized by the Māori Land Court, and the records held by this Court form an invaluable part of the whakapapa of all Māori.' A special bond is a phrase that describes the relationship that a grandparent enjoys with a favoured mokopuna but is certainly not a phrase that describes the feelings I had when I visited my land in Opunake.

In its brutal discussion of the impact of raupatu and so-called land reform in Taranaki, the Waitangi Tribunal observed that: 'Ancestral laws on how lands were held, allocated and inherited were displaced by Government laws that brought Māori into the Government system. ${ }^{50}$ 
While my Pākehā ancestors were building up a family-farming dynasty in Southland, my Māori ones in Taranaki were prevented from making any decisions at all about their land in Opunake, land they had occupied for hundreds of years. With every generation, my mother's family built their wealth and their attachment. ${ }^{51}$ With every generation in my Māori family, wealth and attachment diminished. As the Tribunal put it:

A more particular prejudice was caused by the increased alienation of Māori land, multiple land ownership, fragmentation of title, title dispersal, absentee ownership, uneconomic interests, missing owners, unbankable titles, tenant farming, rent dispersal and administrative control by Māori Land Court, the Māori Trustee, and, later, the Māori Affairs Department. In social and cultural terms, Māori land has been made an illusory and meaningless asset. ${ }^{52}$

This statement induces a kind of writer's block in me. What do I do with it? Is it true that Orimupiko 22 is an illusory, meaningless and under-performing asset? Am I prepared to let this statement be true? How can I turn this statement around and try and enact one of the teachings of Parihaka leader Tohu Kakahi who said:

Ka whakahaere tikanga koe moo te kino kai mate i te pai

You provide the means to overcome evil with good. ${ }^{53}$

To escape the injustice of the recent history of Orimupiko 22 and the 27,000 plus other blocks of remaining Māori freehold land, I can pan outwards and take a longer view of historical time. Philosopher Fernand Braudel was getting at the same thing when he described history not as a 'process of full of historical novelty and loss' but rather as 'endless repetitions and stable structures that stubbornly endure for long times'. ${ }^{54}$ Braudel argued this timescale offered refuge because it stepped way back from recent miseries and hardships and considered, instead, the 'majestic immobility' of the natural world.

\section{Scale}

Seven thousand years ago part of Te Maunga Taranaki's summit collapsed. The south-west section of the mountain, between what is known today as Phantom's Peak and Bob's Bluff, gave way. The former peak became an amphitheatre. Volcanic ash and debris - boulders, molten rock, stones, pebbles, bubbling mud, boiling water, ash and cinders - poured down the side of the mountain, flattening everything in its path. Forests were felled, hills destroyed, rivers filled and still the lahar kept flowing, out on past the present coastline at Opunake. This event, known by volcanologists as the Opua Formation, is the one that felled the forest on Orimupiko 22.

This volcanic debris avalanche coated the earth with up to five metres of ash and stone and gravel from inside the mountain. Between 1968 and 1973 geologist Vince Neall mapped the Opua Formation and many others during field-work for his doctorate at Victoria University. He radiocarbon dated wood, charcoal and peat samples from tephras (volcanic fragments) and lahars (volcanic rock debris deposits) and so constructed 'a chronology for the diverse volcanic and climatic events'. ${ }^{55}$

Neall found in the soil ample evidence of the mountain's generosity. Taranaki had given his land oil, natural gas and coal, charcoal, aggregate, lime, copper, manganese, kokowai (red ochre), sulphur, silver and even tiny specks of gold hidden in the 'quartz veins of silicified andesties in the Kaitake Range'. ${ }^{56}$ The first oil well was drilled off the coast of the place that had only just become New Plymouth in 1866, less than a year after British troops had defeated Taranaki iwi at Te Morere (Sentry Hill), built a redoubt at Opunake and begun their long military occupation of that part of the coast. 
Although the Opua Formation is 7000 years old, in his research report Neall described it as 'new'. Lava flows on the mountain's southern flank, deposited less than 3500 years ago, were 'youthful'. About 500 years ago, small nuees ardentes erupted on the western crater of the mountain, 'reducing much of the native forest on the north-western slopes to carbonised $\operatorname{logs}{ }^{57}$ Then the forests ignited and burnt. More recently still, only 350 years ago, the Burrell Lapilli [an air-fall pumace on Taranaki's south-eastern slopes] erupted. Umu were found.

Neall made no comment on these very recent events. He merely noted that they happened. As did yesterday. The time of history is a shimmering slick on the surface of the time of the volanco. In this sense, the perspective of a volcanologist is closer to the perspective of historian Te Miringa Hohaia whose 'foundation story for Maunga Taranaki' begins in the time before te maunga as we know him now, in the lover's fight that forced Taranaki (formerly known as Pukeonaki) to leave Taupoo. ${ }^{58}$

Māori time is measured by kōrero while a volcanologist's is measured by maps. Three New Zealand Geological Survey maps for New Plymouth, Egmont and Manaia paint time in joyful flows of pebbled puce, orange, yellow and pink. The shallow time of the Opua Formation in Opunake is marked by three shades of pink while the more recent Holocene events, such as the Maero Debris Flows (the collective name for the 14 plus debris flows of the past 500 years) are a babyish yellow. The explosions of the Pleistocene period are mapped in lime greens and brown while the Sugar Loafs [the andesites off the coast of New Plymouth], created at the very start of the Pliocene - 1.6 million years ago - are a very hot pink.

The back of Neall's booklet has a picture of the 'western Taranaki lahar landscape, showing the lahar mounds of the Pungarehu Formation and profile of Egmont volcanic ring plain on skyline'. Parihaka is here among the hillocks and so is the little town of Pungarehu with its derelict primary school and quiet main-street.

23,000 years ago, Neall writes, 'a major explosive eruption occurred, triggering large scale cone collapse, and large quantities of rock, sand and mud (over $6 \mathrm{~km}$ ) slid westwards as a huge lahar to beyond the present coastline, forming the Pungarehu Formation'. ${ }^{59}$ One of these lahars is Purepo. In 1881, government soldiers, police and volunteer militiamen helped push an Armstrong canon onto Purepo and turned its black eye down on the 2000 people sitting on the ground at Parihaka. They called the hill Rolleston, after the recently deposed Native Minister.

Paritutu, a monolithic rock by the New Plymouth Port, and the surrounding Sugar Loaf islands, marks the northern boundary of Taranaki iwi rohe. These andesites are rocks formed by fire. J. J. Stipp, a volcanologist from the University of Miami, has tested a sample of Paritituu andesite and estimated it was 1.74 million years old, give or take 300,000 years on either side. ${ }^{60}$

\section{Conclusion}

Considered on a volcanic time-scale, the New Zealand that we live in now is the most insignificant of blips as are the wars of the nineteenth-century. This longer view provides a comforting, Taranaki-centric perspective on Taranaki whenua but it does not resolve the chaos wrought by the wars, confiscation, return and subsequent leasing (either perpetual or shorter-term) of our land. It is impossible for me, as an uri (descendant) of Taranaki, to write a detached account of the chaotic events endured by my ancestors. I cannot step back and survey the battleground because the war is embedded in the very mechanisms by which we 'own' our land. The confusion is not over, so finding a truthful, authentic way to describe and narrate this confusion is a historical and contemporary problem. Although I was researching the past I was also researching the present. The trust that administers Orimupiko 22 continues to battle along, trying to draw 'disengaged' owners back to their land. We have discussed how 
we can have a more active role in caring for our block and we have approached the Mullin family with some suggestions. Meantime, when the current owners die, succession processes are likely to further fragment ownership and so slow decision-making even further. There are many challenges to engaging with our land and it is easy to understand why so many owners whether through ignorance, fatigue or cynicism - decide to stay away or limit involvement to banking whatever small return their shares earn. This observation has relevance beyond Orimpiko. There are 26,556 remaining blocks of Māori land and most of these blocks are either underdeveloped or ignored by owners. I am convinced that research into these blocks will unravel similar knots of confusion and pain, protest and tenacity, the blunt wounds of ignorance and misinformation. ${ }^{61}$ Even when owners are 'engaged', there are multiple challenges, including the retention of land in the face of compulsory taking for new roads or other infrastructure. ${ }^{6}$

My inability to deliver dispassionate analysis does not make this research any less historical, forensic or analytic. Rather, my style of writing and narration demonstrates that for some chaotic events, a historian might have to be content with a slightly 'hazy idea' of how an event or place fits into a bigger picture, or of what an event truly means. As this article has shown, the war stories that link real tangata to actual bits of whenua can be excruciating, sad and tortuous but the stories can also reveal persistence and vision. I acknowledge the wisdom and courage of my Wallace whanau aunties who, in the 1970s, decided to keep back a portion of the Mullins's rent payments to build up a kitty for education or other purposes to be decided on by trustees. I remain hopeful that the haze will clear, one day, and the chaos will end. In the meantime, I have become a farmer of sorts, digging through records, letting some air into them, waiting to see what might pop up. This is one way, at least, that I am able to care for my land. 
${ }^{1}$ This article was first presented as at short paper at Articulating Aotearoa He Rau Tumu Kōrero Māori Historians' Sympoium, Te Matau a Māui, 4-6 July 2012. It was further developed and presented again at the Stout Research Centre in October 2012, and I am grateful to comments from audiences members and colleagues at both events. I would also like to thank Lydia Wevers and Richard Hill for their collegial support and encouragement while I was an honorary fellow at the Stout Research Centre in 2012.

${ }^{2}$ James Belich, The New Zealand Wars and the Victorian Interpretation of Racial Conflict (Auckland: Penguin, 1986), 16.

${ }^{3}$ Peter Stanley, Black Saturday At Steels Creek (Melbourne: Scribe, 2013).

${ }^{4}$ Maria Tumarkin, 'What it means to be a real journalist', Inside Story, Melbourne, http://inside.org.au/what-itmeans-to-be-a-real-journalist, accessed June 4, 2013.

${ }^{5}$ Stanley, 'Authors Note and Acknowledgements', Black Saturday, 217.

${ }^{6}$ Andrew Chapman, 'Foreword', Black Saturday, x.

${ }^{7}$ This article has been peer reviewed by the Wallace whanau and others. I want to thank John Baxter, Blair Anderson, Aunty Margaret and Aunty Betty, Paora and Haimona Walker, Mahara Okeroa, Ngaahina Hohaia, Taku Parai, Leo Buchanan, Dion Tuuta, Jamie Tuuta, Honiana Love, Kathie Irwin and the other Māori landowners who have generously shared their knowledge. I also want to thank the Mullin family for reading this article. After this process, the article was peer reviewed by two anonymous academic readers. I am very grateful for these (highly critical) reports because they helped clarify my arguments. For example, one reader advised: '...it is important to remember that you are writing for a wider audience that will want dispassionate analysis, and a sense of what the topic means beyond that personal significance'.

${ }^{8}$ Linda Tuhiwai Smith, 'Kaupapa Maori Research', in Marie Battiste, ed., Reclaiming Indigenous Voice and Vision (Vancouver: UBC Press, 2000), 225-247. See also Linda Smith, Decolonizing Methodologies: Research and Indigenous Peoples (London: Zed Books, 1999). The most recent articulations of my struggles are Rachel Buchanan, 'Beating Shame: Parihaka and the very long sorry', Te Pouhere Kōrero 6 (2012): 55-82 and Rachel Buchanan and Maria Tumarkin, 'Bread and breath: two reflections on the ethics of (doing) history', Australian Humanities Review, 52 (2012), viewed June 5, 2013,

http://epress.anu.edu.au/apps/bookworm/view/Australian+Humanities+Review+-+Issue+52,+2012/9881/06Buchanan\%20Tumarkin.html, accessed June 5, 2013.

${ }^{9}$ Laura Troiano, 'Slippery When Wet: A Young Historian's Journey into Creative Non-fiction', Rethinking History: The Journal of Theory and Practice 16, 1 (2012): 98.

${ }^{10}$ Māori Land Court Aotea office (MLCA), Grant under the West Coast Settlement (North Island) Act 1880 and The West Coast Settlement Reserves Act 1881, Orimupiko Block Order file.

${ }^{11}$ Different versions of this article have been presented at a meeting of the Orimupiko 22 Ahu Whenua Trust in Wanganui in September 2012 and at the trust's AGM at Orimupiko Marae in January 2013.

${ }^{12}$ Richard Boast and Richard Hill, 'Introduction', in Richard Boast and Richard S. Hill, eds., Raupatu: The

Confiscation of Maori land (Wellington: Victoria University Press, 2009), 3-4.

${ }^{13}$ Boast and Hill, Raupatu, 11.

14 'Foreword', Discussion Document, ‘Te Ture Whenua Māori Act 1993 Review Panel', Wellington, March 2013.

15 'Executive Summary', Discussion Document, Review Panel, 3-41.

${ }^{16}$ This research has formed the basis for two separate submissions to Te Ture Whenua Māori Act Review Panel, one in October 2012 and another in May 2013.

17 'Māori Freehold Land - 2010 North Island', map published in Māori Agribusiness in New Zealand: A Study

in the Māori Freehold Land Resource (Wellington: Ministry of Agriculture and Forestry, 2011).

${ }^{18}$ Basil Keene, 'Musket Wars - Musket wars overview', Te Ara - the Encylopedia of New Zealand, http://www.teara.govt.nz/en/musket-wars/page-1, accessed June 4, 2013.

${ }^{19}$ Keenan, Danny 'New Zealand wars - North Taranaki war, 1860-1861', Te Ara - the Encylopedia of New Zealand, http://www.TeAra.govt.nz/en/new-zealand-wars/page-4, accessed June 4, 2013.

${ }^{20}$ Michael Belgrave, Historical Frictions: Māori Claims \& Reinvented Histories (Auckland: Auckland University Press, 2005), 218.

${ }^{21}$ Ibid., 247.

${ }^{22}$ Ibid., 250.

${ }^{23}$ Waitangi Tribunal Archive (WTA), Janine Ford, 'The Administration of the West Coast Settlement Reserves in Taranaki by the Public, Native and Maori Trustees 1881-1976', A report for the Waitangi Tribunal for Wai 143 Taranaki Claim (December 1995), v.

${ }^{24}$ Ibid., 98. 
${ }^{25}$ Field notes, Oriumpiko 22, 17 May 2012. Carl and John Mullin have read this article and approved the use of this exchange, including the mention of the dead child.

${ }^{26}$ Personal communication, Paul Walker, September 17, 2012.

${ }^{27}$ See MLCA, Orimupiko Block Order file.

${ }^{28}$ Ford, 'West Coast Settlement', 16.

${ }^{29}$ Dion Tuuta, 'Perpetual Leasing in Taranaki, 1880-2008', in Boast and Hill, Raupatu, 236.

${ }^{30}$ Katarina Mataira, Te Atea (Wellington: Department of Education, 1975), 1.

${ }^{31}$ MLCA, 'Grant under the West Coast Settlement (North Island)' Orimupiko Block Order File.

${ }^{32}$ Ford, 21.

${ }^{33}$ Ibid., 23. For a broader narrative about roads and the colonization of Taranaki, particularly te pahuatanga o

Parihaka, see Rachel Buchanan, 'Road, Telegraph, Lighthouse', The Parihaka Album: Lest We Forget,

Wellington: Huia Books, 2009), 73-94.

${ }^{34}$ Ford, 36.

${ }^{35}$ Ibid, 42-43.

36 Ibid, 47.

${ }^{37}$ Taranaki Minute Book, no. 3, Māori Land Court, facsimile in collection of National Archives of New

Zealand, Wellington. Grant no. 3924, Partition case, 15 February 1887, 245.

${ }^{38}$ Ford, 29-30. See also Taranaki Minute Book, no.16, 223-226.

${ }^{39}$ Ford, 59.

${ }^{40} \mathrm{PKW}$ is a successful Māori agricultural business, innovating and working hard to overcome the injustice of perpetual leases. For an insight into the incorporation see Parininihi Ki Waitotara Annual Report 2012.

${ }^{41}$ Tuuta, 'Perpetual leasing', 242.

${ }^{42}$ WTA, Ben White, 'Supplementary Report on the West Coast Settlement Reserves', A Report commissioned by the Waitangi Tribunal for the Taranaki claim, February 1996, 6.

${ }^{43}$ Ibid., 2.

${ }^{44}$ Ibid, 15-17.

45 All quotes in this paragraph from Native Land Court documents in the Orimupiko Block Order File.

${ }^{46}$ Ford, Appendix A, 'Settlement Reserves'.

${ }^{47}$ All quotes from Orimupiko Block Order File. Dates indicate the relevant document.

${ }^{48}$ Hannah Bramley (nee Wallace), letters in the collection of Leo Buchanan.

${ }^{49}$ White, 'Supplementary Report', 21.

${ }^{50}$ Waitangi Tribunal, The Taranaki Report: Kaupapa Tuatahi (Wellington: Ministry of Justice, 1996), 277.

${ }^{51}$ My mother, Mary English, grew up at the Rosedale, the English family homestead in down country Southland. Mum told me that the farm was set up five generations ago 'when my great-grandfather bought the land from Mr Rose'. It has been handed down from father to sons ever since.

52 The Taranaki Report, 285.

${ }^{53}$ Tohu Kakaki, Hune 1895, transcribed by Te Kaahui Karere and translated by Te Miringa Hohaia, 'Ngaa Puutaketanga Koorero Moo Parihaka' in M. Hohaia, G O’Brien, L. Strongman, eds., Parihaka: The Art of Passive Resistance (Wellington: Victoria University Press, 2001), 60.

${ }^{54}$ Fernand Braudel, cit. Berber Bevernage, History, Memory and State-Sponsored Violence (London: Routledge 2012), 113

${ }^{55}$ Vince Neall, 'Geological Map of New Zealand 1:50 000 Sheets P19, P20, P21 New Plymouth, Egmont and Manaia', DSIR, New Zealand Geological Survey (1979). Maps and explanatory booklet.

${ }^{56}$ Ibid., 'Sheets P19, P20, P21', 31.

${ }^{57}$ Ibid., 'Sheets', 6.

${ }^{58}$ Hohaia, Te Miringa, 'The Foundation Story for Maunga Taranaki', unpublished paper, July 2010.

${ }^{59}$ Neall, 5.

${ }^{60}$ Ibid., 7.

${ }^{61}$ For an example of personal narration about Māori land, from a narrator on the opposite coast, is Pareputiputi Nuku, 'I kī i nohoia anō tēnei poraka e aku tūpuna', I repeat, these are my ancestral lands' paper, presented at Articulating Aotearoa He Rau Tumu Kōrero Māori Historians’ Symposium, Te Matau a Māui, July 4 - 6, 2012, http://www.mai.ac.nz/content/kī-au-i-nohoia-anō-tēnei-poraka-e-aku-tūpuna-i-repeat-these-are-my-ancestrallands, accessed 5 June 2013.

${ }^{62}$ For example, writer Patricia Grace's battle to save her whenua, 'Reserve status sought for land on expressway route', Television New Zealand News, http://tvnz.co.nz/national-news/reserve-status-sought-land-expresswayroute-5444457, accessed June 5, 2013; See, also, Joel Maxwell, 'Sacred land recognised', Kapiti Observer, January 24, 2012, http://www.stuff.co.nz/dominion-post/news/local-papers/kapiti-observer/6297849/Sacredland-recognised, accessed June 5, 2013. 